\title{
SENI TEREBANG GEBES DALAM PROSESI RITUAL HAJAT LEMBUR PADA GRUP CANDRALIJAYA DI KECAMATAN TANJUNGJAYA KABUPATEN TASIKMALAYA
}

\author{
Leli Deniati \\ Universitas Muhammadiyah Tasikmalaya \\ Lelideniati4@gmail.com \\ Denden Setiaji, M.Pd \\ Universitas Muhammadiyah Tasikmalaya \\ satyaajisatya@gmail.com
}

\begin{abstract}
ABSTRAK
Penelitian ini bertujuan untuk mengetahui dan mendeskripsikan tentang seni terebang gebes dalam prosesi ritual hajat lembur pada Grup Candralijaya di Kecamatan Tanjungjaya Kabupaten Tasikmalaya, yang mengkaji permasalahan tentang bagaimana mengenai struktur penyajian seni serta peran dan fungsi seni terebang gebes pada hajat lembur. Jenis penelitian ini adalah penelitian deskriptif analitik dengan pendekatan kualitatif. Data yang diperoleh adalah dengan teknik observasi, wawancara, dan dokumentasi. Instrumen utama dalam penelitian ini adalah peneliti itu sendiri menggunakan alat bantu berupa lembar wawancara, catatan lapangan, dan alat rekam berupa handphone. Temuannya mengenai struktur penyajian musik terebang gebes Grup Candralijaya dalam rangkaian ritual hajat lembur yang terbagi kedalam tiga bagian meliputi bagian pembuka pertunjukan, bagian isi dan penutup. Sedangkan peran dan fungsi seni diklasifikasikan menjadi fungsi primer yaitu sebagai sarana ritual, ungkapan pribadi dan presentasi estetis.
\end{abstract}

Kata Kunci : Seni terebang gebes Grup Candralijaya

\section{ABSTRACT}

This research aims to find out and describe the art of terebang gebes in the procession of overtime rituals in the Group Candralijaya in Kecamatan Tanjungjaya Kabupaten Tasikmalaya, which examines the problem of how about the structure of the presentation of art and the role and funsction of the art of splashing on overtime. This type of research is analytic descriptive research with a qualitative approach. The data obtained are by observation, interview, and documentation techniques. The main instrument in this study was the researcher himself used aids in the form of interview, field notes, and a recording device in the form of a handphone. His finding regarding the structure of the music presentation of terebang gebes Group Candralijaya in a series of overtime rituals which are divided into three parts including the opening part of the show, the contents section and the clousing section. While the role and function of art are classified into primary function, namely as a means of ritual, personal expression and aesthetic presentation.

Keywoard : Art terebang gebes in the Group Candralijaya 


\section{A. PENDAHULUAN}

Jawa Barat merupakan salah satu Propinsi di Indonesia yang memiliki keanekaragaman seni, budaya, suku, bangsa yang berbeda. Dengan adanya perbedaan tersebut menjadikan keanekaragaman yang ada di Jawa Barat berkembang dengan ciri khasnya masing-masing. Tanah priangan ini termasuk daerah yang kaya akan kesenian tradisional dengan berbagai macam bentuk dan jenisnya. Kesenian merupakan bagian dari kebudayaan yang tidak lepas dari kehidupan manusia, karena kesenian merupakan hasil karya cipta, karsa rasa yang sebelumnya tidak di kenal dan akhirnya menjadi sebuah karya yang indah, seperti di ungkapkan oleh Langer (2000:68) bahwa,"kesenian adalah sesuatu ciptaan bentuk yang hidup, yang di dalamnya ada dinamika, ada kesatuan logis dalam dirinya". selain itu Sumardjo (2000:10) menegaskan bahwa,"kesenian adalah sesuatu yang memuat hal-hal yang transendental, sesuatu yang tak kita kenal sebelumnya, dan kini kita kenal lewat karya seniman seseorang".

Berbicara tentang kesenian yang hidup dan berkembang di masing-masing daerah, dalam konteks, seni merupakan salah satu produk masyarakat yang memiliki proses perjalanan cukup panjang dan mempunyai tradisi secara turun temurun. Kehadiran seni itu sendiri terbentuk atas dasar dukungan masyarakat penyangganya yang memiliki tujuan dalam mengekpresikan segala keinginannya. Seperti yang di ungkapkan Caturwati (2007:160) bahwa,"seni tradisi merupakan suatu bentuk seni yang bersumber dan berakar, serta telah dirasakan sebagai milik sendiri oleh masyarakat lingkungannya". Karya seni yang ada dapat di artikan sebagai hasil karya atau hasil kerja seniman untuk menghasilkan sebuah karya yang dapat diakui oleh masyarakatnya. Dari sekian banyak kesenian tradisional yang berkembang di daerah tatar sunda Jawa Barat seperti di Tasikmalaya berkembang salah satu seni rakyat yaitu terebang gebes.

Masyarakat Kabupaten Tasikmalaya terkenal sebagai masyarakat yang menjungjung tinggi tradisi leluhurnya, oleh sebab itu bentuk kesenian yang ada dan berkembang di Tasikmalaya tidak lepas dari nilai-nilai tradisi yang ada. Nilai tradisi itu sendiri pun di jadikan dasar dalam sebuah pertunjukan tersebut, bahkan hal yang tersirat dalam unsur-unsur pertunjukan seni terebang gebes seperti sesaji dan kemenyan yang dibakar menjelang pementasannya.

Di Cirangkong Desa Cikeusal Kecamatan Tanjungjaya Kabupaten Tasikmalaya terdapat seni buhun tradisional yaitu "terebang gebes" yang masih hidup dan masih bertahan, hal itu menjadikan kesenian tersebut memiliki daya tarik yang cukup besar. Pada awalnya masyarakat sekitar kampung Cirangkong sudah mengenal kesenian ini pada acara-acara tertentu, akan tetapi pengenalannya yang hanya sepintas menyebabkan kurangnya pemahaman pertunjukan seni buhun yang mendalam terutama masyarakat Kabupaten Tasikmalaya itu sendiri.

Terebang gebes merupakan sebuah musik ansamble yang memainkan alat musik terebang. Terebang gebes merupakan alat musik rebana yang digunakan sebagai media dakwah. Pada mulanya pertunjukan seni terebang gebes dalam pertunjukannya memperlihatkan atau menonjolkan kekuatan fisik, akan tetapi seiring dengan perkembangan zaman dan proses penyebaran agama islam terjadi perubahan struktur dan fungsi pertunjukan. Pertunjukan terebang gebes saat ini lebih diutamakan untuk mengiringi sholawatan atau pujian terhadap Allah SWT dan Rasullulah SAW atau mengiringi vokal seperti beluk. Kesenian ini lebih di utamakan sebagai hiburan seharihari, ritual keagamaan seperti peringatan hari-hari besar Nasional, hajatan pernikahan, 
dan seperti di Cirangkong di gunakan sebagai tradisi hajat lembur, dengan menggunakan waditra terebang saja.

Berkaitan dengan kesenian terebang gebes di Cirangkong Desa Cikeusal Kecamatan Tanjungjaya ada sebuah Grup yang bernama Candralijaya yang dipimpin oleh bapak H.Ipin Saripin, AMa.Pd . Seni buhun ini sudah berkembang sejak berdirinya Kabupaten sukapura. Nama Candralijaya diambil dari sebuah tokoh dari masyarakat yang mengembangkan kesenian terebang gebes yaitu Mbah Candrali dan dari sebuah nama lapangan sepak bola di Kampung Cirangkong yaitu Candralijaya atas gagasan H.Ipin Saripin, AMa.Pd selaku pimpinan sanggar.

Tradisi ritual hajat lembur merupakan salah satu ritual yang selalu di laksanakan Grup Candralijaya sebagai bentuk syukuran kepada Allah SWT pada saat petani melaksanakan panen. Dimana didalamnya terlihat dari nilai dan makna yang terkandung dalam prosesi tradisi ini, yang pada dasarnya bukan semata-mata untuk acara ritual saja tetapi jauh dari hal itu ada keterkaitan dalam sistem kepercayaan, sistem pengetahuan, dan praktik masyarakat dalam memaknai dan menghargai lingkungan bagi kelangsungan masyarakat itu sendiri. Apalagi dengan adanya perkembangan zaman dan arus globalisasi yang begitu kuat di zaman yang modern ini memberi banyak pengaruh asing secara tidak langsung dalam minat dan pelestarian kesenian tradisional. Terbukti dengan semakin sedikitnya minat masyarakat sekitar terhadap kesenian terebang gebes terutama generasi muda. Hal ini menjadi tuntutan bagi para seniman untuk mampu beradaptasi dengan perkembangan zaman tersebut agar kesenian ini bisa lebih di lestarikan.

Maka dari itu warga Kampung Cirangkong Desa Cikeusal Kecamatan Tanjungjaya Kabupaten Tasikmalaya mengadakan ritual hajat lembur pada tiap tahunnya sebagai wujud syukur setelah musim panen tiba. Hajat lembur ini menampilkan pertunjukan seni "terebang gebes" dan lima kesenian buhun lainnya.

Berdasarkan latar belakang tersebut, peneliti tertarik untuk mengkaji lebih dalam mengenai kesenian terebang gebes Grup Candralijaya dalam prosesi ritual hajat lembur di Kecamatan Tanjungjaya Kabupaten Tasikmalaya. Untuk itu peneliti mengangkat penelitian dengan judul "Seni Terebang Gebes dalam prosesi Ritual Hajat Lembur pada Grup Candralijaya Di Kecamatan Tanjungjaya“.

Peneliti berharap semoga seni buhun tradisional terebang gebes Grup Candralijaya di Kampung Cirangkong Desa Cikeusal Kecamatan Tanjungjaya Kabupaten Tasikmalaya ini dapat lebih dikenal dan di tumbuhkembangkan oleh seluruh masyarakat, serta kegigihan dan kecintaan Bapak H.Ipin Saripin AMa.Pd selaku pimpinan Grup Candralijaya terhadap pelestarian seni buhun terebang gebes bisa membuahkan hasil yang lebih baik lagi.

\section{B. Metode Penelitian}

Metode yang digunakan pada penelitian ini adalah deskriptif kualitatif. Peneliti menggunakan pendekatan kualitatif, karena penelitian dilakukan pada kondisi yang alamiah. Penggunaan metode ini dengan tujuan untuk memaparkan atau mendeskripsikan peristiwa pada saat penelitian berlangsung. Dan menggunakan beberapa teknik pengumpulan data. Teknik pengumpulan data merupakan langkah yang paling utama dalam sebuah penelitian. Karena tujuan utama dari penelitian adalah mendapatkan data.

Teknik pengumpulan data yang diperlukan adalah teknik pengumpulan data yang paling tepat, sehingga benar-benar didapatkan data yang valid. Teknik pengumpulan data yang dilakukan peneliti bertujuan untuk memperoleh data dari semua 
masalah penelitian, yaitu mengenai perkembangan struktur, fungsi seni terebang gebes dalam prosesi ritual hajat lembur pada Grup Candralijaya di Kecamatan Tanjungjaya Kabupaten Tasikmalaya.

Adapun teknik pengumpulan data yang akan dilakukan peneliti pada penelitian kali ini yaitu dengan melalui observasi, wawancara, studi dokumentasi dan studi pustaka.

Observasi atau pengamatan merupakan salah satu teknik pengumpulan data/fakta yang cukup efektif untuk mempelajari suatu sistem. Observasi adalah pengamatan langsung suatu kegiatan yang sedang berjalan.

Wawancara merupakan proses komunikasi atau interaksi untuk mengumpulkan informasi

dengan cara tanya jawab antara peneliti dengan informan atau subjek penelitian. Selain itu, wawancara merupakan proses informasi atau keterangan yang telah di peroleh lewat teknik yang lain. Sugiyono (2005:82) menjelaskan bahwa dokumentasi merupakan catatan peristiwa yang sudah berlalu. Dokumentasi dapat berupa tulisan, gambar, atau karya-karya monumental dari seseorang. Studi dokumentasi digunakan agar lebih menguatkan data yang sudah didapat dari observasi.

Dokumentasi yang peneliti lakukan berupa foto, video, partitur, audio rekaman wawancara dari narasumber. Instrumen penelitian adalah alat yang digunakan untuk mengumpulkan, memeriksa, menyelidiki suatu masalah. Instrument penelitian dapat diartikan pula sebagai alat untuk mengelola, menganalisis, memecahkan suatu persoalan atau mengkaji suatu hipotesis. Instrumen dari penelitian ini adalah penelitian itu sendiri yang dibantu oleh alat pengumpulan data yang lainnya agar menemukan kejelasan atas permasalahan yang diteliti dan dapat dikembangkan menjadi suatu instrumen.
Analisa data yang dilakukan dalam penelitian secara interaktif melalui proses mereduksi data, penyajian data dan penarikan kesimpulan yang diperoleh dari lapangan. Untuk itu maka perlu dicatat secara rinci dan teliti. Mereduksi data berarti merangkum, memilih hal-hal yang pokok, memfokuskan pada hal-hal yang penting. Dengan demikian data yang telah direduksi akan memberikan gambaran yang jelas (Sugiyono, 2011:336). Langkah pertama yang peneliti lakukan dalam menganalisis data yang teah diperoleh selama pengumpulan data yaitu mereduksi data.

Peneliti akan memilih data pokok yang relevan dengan kajian penelitian. Langkah kedua yang dilakukan adalah mendisplay data secara naratif deskriptif. Data yang diperoleh akan disajikan kedalam bentuk uraian, bagan atau table sehingga akan lebih mudah dipahami. Dalam penelitian kualitatif, penyajian data biasa dilakukan dalam bentuk uraian teks yang bersifat naratif, bagan hubungan antarkategori, grafik dan chart (Sugiyono, 2011:339). Langkah ketiga adalah conclusion, drawing atau verification. Peneliti menyimpulkan kajian dari penelitian tentang seni terebang gebes serta peran dan fungsinya. Menurut Miles dan Huberman (Sugiyono,2011:343) kesimpulan dalam penelitian merupakan sebuah temuan yang dapat berupa deskripsi atau gambaran suatu objek yang sebelumnya masih remangremang sehingga setelah diteliti menjadi jelas, dapat berupa hubungan kasual atauinteraktif, hipotesis, atau teori.Tiga jenis kegiatan utama dalam analisis data merupakan proses siklus dan interaktif. Peneliti harus siap bergerak diantara empat "sumbu" kumparan itu selama pengumpulan data. 


\section{HASIL PENELITIAN DAN PEMBAHASAN}

Berdasarkan hasil penelitian akhirnya peneliti mendapatkan beberapa temuan tentang bagaimana struktur penyajian seni terebang gebes serta peran dan fungsi seni terebang gebes pada prosesi ritual hajat lembur di Kecamatan Tanjungjaya Kabupaten Tasikmalaya.

\section{Kehidupan Kesenian Terebang Gebes}

Berdasarkan hasil wawancara Bapak. H. Ipin Saripin, AMa.Pd pada tanggal 27 juni 2019, menjelaskan secara singkat bahwa kesenian terebang gebes Desa Cikeusal telah mengalami pasang surut selama kurun waktu keberadaanya, namun eksistensinya masih dipertahankan mengingat masih adanya kebutuhan masyarakat terhadap kesenian terebang gebes, terutama untuk ritual adat, perayaan dalam suatu hajatan, atau untuk hiburan semata.

Begitu penting arti padi bagi kehidupan manusia. Dalam sudut pandang kepercayaan Masyarakat Cikeusal khususnya, upacara ritual padi pada acara Hajat Lembur menjadi salah satu yang menjadikan kesenian terebang gebes masih bertahan. Cerita yang disampaikan mengenai Dewi Sri ini telah menjadi bahan perenungan masyarakat yang kemudian diaplikasikan kedalam bentuk upacara pengkultusan terhadap Dewi Sri. Salah satu dari ekpresi syukur dari masyarakat Desa Cikeusal ini yaitu dengan menghadirkan bunyi-bunyian atau tetabuhan pada

pada saat pesta panen, sebagai bentuk ungkapan penghormatan dan atas nikmat yang telah diberikan oleh Tuhannya kepada masyarakat.

Menurut hasil wawancara Bapak H.Ipin Saripin, AMa.Pd pada tanggal 21 April 2019, pada zaman dahulu antara terebang gebes dan beluk memiliki perbedaan dalam konteks penyajiannya, terebang gebes hanya dimainkan di sela-sela waktu senggang ketika menunggu padi di sawah, sedangkan beluk dipakai sebagai media komunikasi individu ketika berada di tengah-tengah ladang ataupun di sawah secara bersahutan antara satu dengan yang lainnya. Pada awal struktur penyajian apabila dalam ritual hajat lembur sebagai berikut, tutunggulan dimainkan untuk mengundang masa berkumpul di arena yang ditentukan. Kemudian terebang gebes dimainkan diselasela waktu ketika menunggu padi dipanen, dilanjutkan dengan rengkong dimainkan untuk ritual ampih pare yaitu membawa padi yang dipanen ke leuit atau goah.

Selanjutnya untuk acara inti (ritus) meminta keselamatan dari hasil bumi yang dihasilkan itu, rangkaian acara dilanjutkan malam hari, diawali dengan Syi'iran dengan cara ngahaleuang (dinyanyikan). Lagu yang dipakai dalam syi”'iran yaitu lagu-lagu pupuh seperti, sinom, asmarandana, pangkur, dan dangdanggula. Selain lagu-lagu pupuh, terdapat pula lagu-lagu yang memang dinyanyikan dengan bentuk irama yang bebas tanpa ada tetapan lagu.

Seiring dengan bergulirnya waktu, ritual seperti tersebut di atas kini sudah jarang ditemui di daerah-daerah lainnya di Tasikmalaya. Hal itu disebabkan oleh beberapa elemen-elemen pelengkap dalam sebuah ritual sekarang sudah mulai hilang secara perlahan, contohnya, kerbau yang biasa digunakan untuk membajak sawah sudah tergantikan dengan adanya traktor, leuit sebagai ruang kelengkapan untuk menyimpan padi dalam sebuah bangunan rumah, sekarang sudah mulai ditinggalkan dengan adanya efektifitas dan tawaran perkembangan teknologi yang lebih praktis.

Hal tersebut diatas mengakibatkan terputusnya elemen-elemen dalam sebuah struktur ritual dan perlahan hilang termakan oleh zaman. Akhirnya pada tahun 1969, Bapak H.Ipin Saripin, AMa.Pd membuat 
suatu wadah yang dinamakan Candralijaya sebagai tempat yang mewadahi kesen ian-kesenian yang masih terjaga di Kampung Cirangkong Desa Cikeusal Kecamatan Tanjungjaya Kabupaten Tasikmalaya. Pada waktu yang sama pula Bapak H.Ipin Saripin, AMa.Pd menggabungkan antara seni terebang gebes dan beluk dengan alasan kekhawatiran akan punahnya keseniankesenian yang hidup dan berkembang. Sejak saat itu, kesenian ini mulai dikenal dan sering dipertunjukan, bahkan pada tahun 1989, Grup Candralijaya pimpinan Bapak H.Ipin Saripin, AMa.Pd diundang secara resmi untuk main di Taman Mini Indonesia Indah (TMII) mewakili perwajahan kesenian dari Kabupaten Tasikmalaya di anjungan Jawa Barat.

\section{Faktor Penunjang Pertunjukan Seni Terebang Gebes Grup Candralijaya}

\section{a. Alat Musik atau Instrumen yang dimainkan Grup Candralijaya}

Terkait dengan pembahasan di bab II mengenai alat musik atau instrumen, menurut Tambayong (1992:130), alat musik atau instrumen merupakan suatu alat yang diciptakan untuk menghasilkan bunyi. Alat musik dapat dibedakan dari sumber bunyi dan cara memainkannya, bentuk instrument ini terdiri atas instrumen yang sejenis ada juga bentuk yang berbeda. Misalkan alat musik tiup, pukul dan sebagainya. Hal tersebut berkaitan dengan alat musik atau dalam bahasa Sunda biasa di sebut dengan waditra, yang digunakan oleh Grup Candralijaya yaitu terdiri dari 3 instrumen pokok dengan ukuran dan warna bunyi yang sama. Untuk menghasilkan bunyi terebang ini dihasilkan dengan cara dipukul atau ditepak dengan telapak tangan.

Terkait dengan pembahasan di bab II mengenai seni terebang menurut Jakob Sumardjo (2001:140), seni terebang adalah alat musik tepuk yang menyerupai rebana.
Hal tersebut sesuai dengan hasil wawancara dengan Bapak H.Ipin Saripin, AMa.Pd pada tanggal 20 Juni 2019, yang mengatakan bahwa alat musik atau waditra terebang ini bentuknya hampir mirip dengan rebana, akan tetapi bentuknya besar dan cukup berat karena terbuat dari kayu seperti pohon nangka berat rata-rata $15-30 \mathrm{~kg}$, muka terebang dipasangi kulit kerbau. Untuk muka terebang dipasangi pasak atau slag (ganjal) disekelilingnya seperti bedug.

Setelah itu setiap pasak atau slag (ganjal) disekelilingnya diikat kembali dengan rotan dan sekeliling pasak tersebut diikat kembali dengan tali yang terbuat dari kayu teureup sehingga kayu yang menempel pada kuluwung atau waditra yang dibolongi menjadi kencang, tali tersebut juga mengikat bagian dalam kuluwung supaya awet hingga belasan tahun, akan tetapi pada saat ini kulit kayu teureup sudah sulit didapat, jadi tali yang digunakan dibuat dari tali tambang biasa.

Perbedaan suara yang dihasilkan dari waditra terebang terletak dari pada besar kecilnya kuluwung dan tinggi rendahnya bunyi ketika ditabuh, sedangkan tinggi rendah bunyi yang dihasilkan tergantung pada kencang atau kendurnya kulit yang dipasang pada kuluwung, serta kuat atau tidaknya pemasangan pasak atau slag. Pada waditra ini bagian yang dibolongi diletakan benda yang bernama seser supaya waditra terebang suaranya kuat dan nyaring dengan dipukul sendul untuk menguatkan seser tersebut yang berada didalam waditra terebang.

\section{b. Waktu dan Tempat Pertunjukan}

Berdasarkan hasil wawancara dengan narasumber utama yaitu, Bapak H.Ipin Saripin, AMa.Pd pada tanggal 20 juni 2019 menjelaskan, menurut beliau pada zaman dahulu waktu untuk pertunjukan terebang gebes hanya dilaksanakan pada malam hari, karena konteks penyajian dahulu benar-benar 
mengadu adu kesaktian yang disertai unsur magis (ilmu gaib). Sehingga pertunjukannya hanya dilakukan pada malam hari disebuah lapangan khusus atau bukit.

Namun karena perubahan fungsinya sebagai sarana hiburan maka waktu untuk pertunjukannya kini bisa kapan saja dan dimana saja, dan disesuaikan dengan acara atau kebutuhan pertunjukannya, serta bersifat tentative/belum pasti.

Untuk tempat pertunjukan terebang gebes Grup Candralijaya pada acara hajat lembur dipertunjukan disebuah lapangan dengan dekor panggung yang sederhana.

\section{c. Kostum Grup Candralijaya 1). Pakaian Pangsi}

Berdasarkan hasil wawancara dengan narasumber utama yaitu Bapak H.Ipin Saripin, AMa.Pd pada tanggal 20 Juni 2019 menjelaskan, untuk kostum Grup Candralijaya pakaian yang digunakan yaitu pakaian pangsi. Pangsi merupakan setelan pakaian berupa baju kemeja polos yang agak longgar serta celana yang juga longgar dan panjangnya tidak melebihi mata kaki. Pakaian ini merupakan salah satu pakaian khas adat Sunda warisan sesepuh baheula (nenek moyang) yang eksistensinya perlu dilestarikan.

\section{2). Iket Kepala}

Iket kepala yang digunakan oleh Grup Candralijaya menggunakan iket kepala Sunda. Berdasarkan hasil wawancara dengan narasumber utama yaitu Bapak H.Ipin Saripin, AMa.Pd pada tanggal 20 Juni 2019, iket kepala atau totopong Sunda atau udeng adalah penutup kepala yang terbuat dari kain merupakan bagian dari kelengkapan seharihari pria di pulau jawa. Fungsi dari iket kepala ini berfungsi sebagai kelengkapan berbusana, untuk kain yang digunakan oleh Grup Candralijaya merupakan kain dengan motif batik.

\section{Struktur Penyajian Seni Terebang Gebes Grup Candralijaya}

Untuk membedah struktur seni terebang gebes Grup Candralijaya, peneliti menggunakan teori-teori dari para ahli yang mampu untuk membedah data-data dari hasil temuan dilapangan. Salah satunya teori yang menjelaskan mengenai struktur penyajian pertunjukan,yaitu menurut Djelantik (1999:37) bahwa "kata hajat lembur struktur mengandung arti bahwa didalam karya seni terdapat suatu perorganisasian, ada hubungan tertentu antara bagian-bagian yang tersusun itu". Pendapat tersebut berhubungan dengan struktur seni terebang gebes Grup Candralijaya, terutama pada tahapan-tahapan atau susunan penyajiannya. Tahapan tersebut meliputi bagian pembuka, bagian isi, bagian penutup atau bagian akhir. Semua tahapan tersebut terlebih dahulu telah tersusun dan terkonsep sedemikian rupa melalui proses dan hasil garapan, proses penyajian pertunjukan serta penataan secara menarik. Berikut struktur seni terebang gebes terdiri tiga bagian meliputi:

\section{a. Bagian Pembuka}

Sebelum pertunjukan dimulai pada acara ritual hajat lembur di Kampung Cirangkong dibuka oleh seorang pembawa acara yang memandu acara. Bapak H.Ipin Saripin AMa.Pd selaku pimpinan Grup kesenian Canrdalijaya, Ibu Neneng selaku pelopor adanya Kampung Cirangkong, perwakilan dari pemerintah Kabupaten Tasikmalaya dan satu perwakilan tokoh masyarakat. Setelah itu sambil menyantap hasil bumi yang disediakan oleh masyarakat Kampung Cirangkong, ada beberapa kesenian yang ditampilkan sebelum terebang gebes seperti tutunggulan, rengkong, beluk, terbang sejak dan lais.

Pada bagian pembuka atau bagian pertama pemain terbang gebes dan pelantun beluk membawakan syair beluk menggunakan pola pupuh pangkur. Menurut 
Bapak H,Ipin AMa.Pd pupuh pangkur yang digunakan berbeda dengan pupuh yang biasanya diajarkan disekolah, menurut beliau hal tersebut tidak ada bukunya dalam sejarah melainkan hanya menikuti peninggalan dari nenek moyang saja.

Beluk merupakan tembang Sunda yang menggunakan nada-nada tinggi. Hal tersebut terkait dengan pembahasan dikajian teori bab II, menurut Supandi (1985:23) menjelaskan bahwa:

"beluk merupakan bentuk seni suara bebas dengan pupuh sebagai sumber rumpaka yang banyak menggunakan nada tinggi yang erat dengan nemban atau wawacan (cerita yang dinyanyikan) yang tersusun ceritanya dalam bentuk puisi terutama pupuh. Diantaranya pupuh kinanti, asmarandana, sinom dan sebagainya”.

Akan tetapi beluk yang dimaksud disini berbeda dengan pengertian beluk secara teori yang menyatakan bahwa beluk erat kaitannya dengan nemban atau wawacan (cerita yang dinyanyikan) sedangkan beluk dalam hal penelitian hanya menyanyikan nada-nada tinggi tanpa adanya syair atau cerita.

Cara memainkan terebang gebes pertamanya yaitu para pemain sudah bersiapsiap duduk di panggung dengan kaki kanan menjulur ke depan (nangunjar) untuk menyanggah alat, setelah itu bagian alat atau kuluwung diletakan diatas lutut kaki kiri, tangan kiri menutup kuluwung dan tangan kanan membunyikan permukaan kulit atau membrane kulit dengan cara menepuknya atau digebes, dan untuk posisi penabuh terebang disarankan tegak untuk menjadi tahanan atau tumpuan mengumpulkan tenaga ketika menabuh.

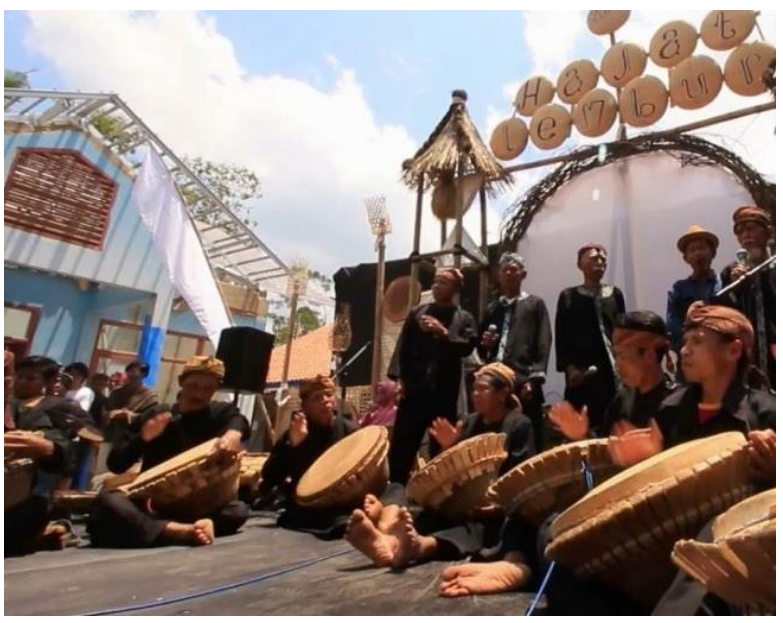

Gambar 4.15 Pertunjukan terebang gebes (Doukumentasi Leli Deniati, 2019)

Aturan tepak terebang gebes terikat oleh aturan irama yaitu tepak jeungjleung, tepak degdog, dan tepak balaganjur, sehingga menghasilkan komposisi bunyi yang beragam. Seni terebang gebes ini termasuk ke dalam jenis ansamble musik dengan menggunakan waditra yang sama yaitu terebang.

Dalam pertunjukan seni terebang gebes pelantun beluk menggunakan pupuh pangkur. Pada bagian pembuka atau awal pertunjukan satu pemain terbang gebes satu orang menabuh terebang selama empat ketuk sebagai langkah awal telah di mulainya pertunjukan seni terebang gebes. Setelah itu baru dimulai semua pemain seni terebang gebes menggunakan pola tabuh jeungjleung, pola tabuh jeungjleung ini memiliki pola tabuh yang sangat sederhana yang memiliki ciri khas dalam setiap ketukannya dan memiliki tekanan pada ketukan pertama atau aksen sebagai tanda motif tabuhan pertama yaitu motif jeungjleung. Pada bagian ini merupakan sebagai pemanasan para penabuh terebang. Berikut pola tabuh jeungjleung yang di notasikan oleh peneliti: 


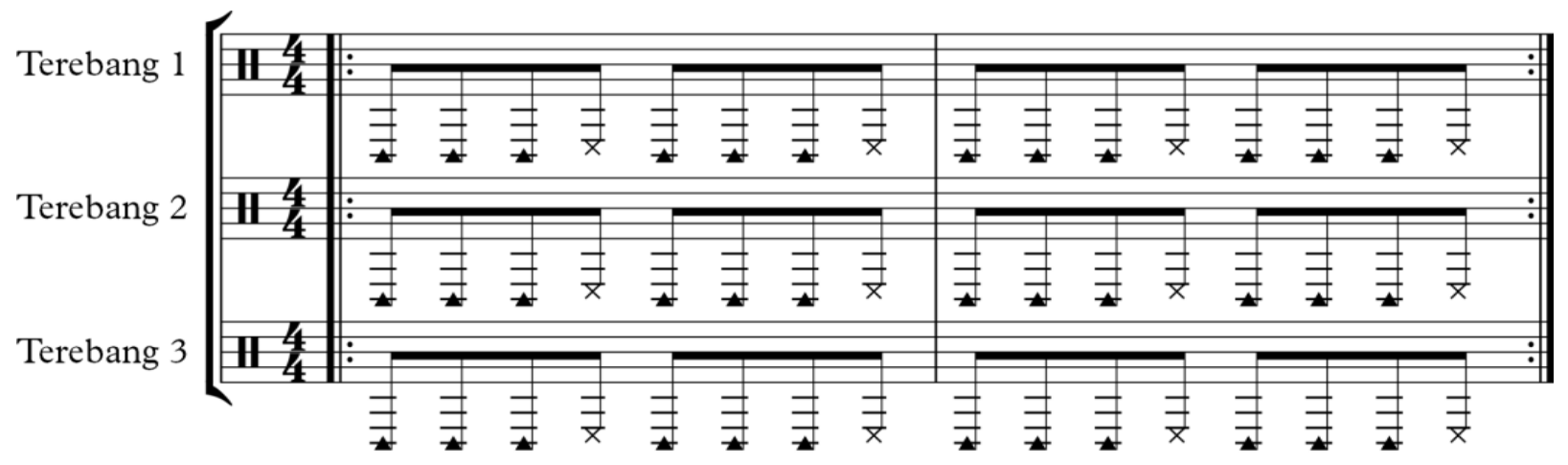

Keterangan :

$\Delta=\mathrm{Deg} / \mathrm{dog}$

$\mathrm{x}=$ Dhak

Gambar 4.2 Notasi pola tabuh jeungjleung

\section{b. Bagian Isi}

(Transkrip Leli Deniati, 2019)

Setelah bagian pertama dianggap cukup, selanjutnya mulai bagian kedua yaitu isi dengan pola tabuhan degdog, dinamakan motif degdog apabila dua alat terebang dimainkan dengan ritme yang berbeda, kedua tabuhan tersebut saling bersautan, sehingga menghasilkan kesan bunyi yang terdengar "degdog".

Pada bagian isi merupakan bagian inti dari pertunjukan seni terebang gebes Grup Candralijaya. Bagian ini ditandai dengan mulainya perubahan pola ritmik dari jeungjleung ke pola tabuh degdog. Disebut pola tabuh degdog yaitu apabila tiga alat terebang gebes dimainkan dengan ritme

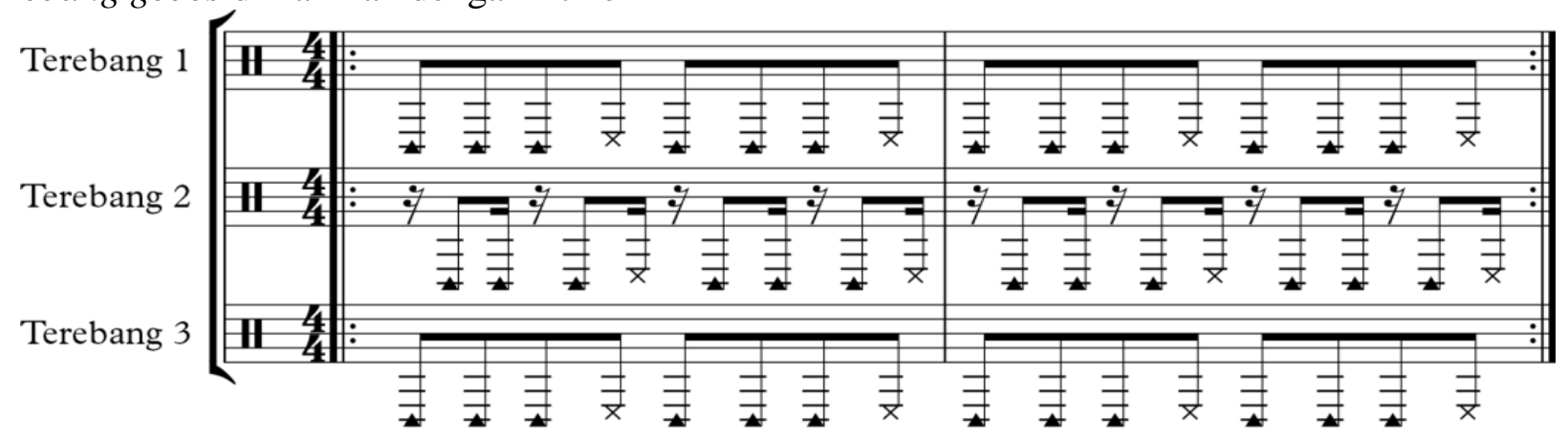

Keterangan :

$\Delta=\mathrm{Deg} / \mathrm{dog}$

$\mathrm{x}=$ Dhak

Gambar 4.3 Notasi pola tabuh degdog

(Transkrip Leli Deniati, 2019) 
Pada bagian ini masih menggunakan pola ritmik degdog yang berfungsi sebagai penanda menuju bagian inti. Akan tetapi, beberapa waktu kemudian terdapat beluk yang bebunyi $A u$ dengan iringan pola ritmik degdog. Setelah itu terdapat frase beluk yang baru aeo selama beberapa waktu masih dengan iringan pola tabuh degdog. Setelah pola tabuh degdog masuklah pelantun beluk dengan vocal ala dan $e$ dengan kembali ke pola ritmik jeungjleung lalu kembali lagi dengan vokal aeo dan alae fungsi dari pola ritmik jeungjleng ini merupakan sebuah jembatan dimana pada bar sebelumnya menggunakan pola ritmik degdog.

selanjutnya menggunakan iringan pola ritmik balaganjur dimana semua alat terebang memainkan ritme yang berbeda dan dengan frase yang baru. Pada bagian ini terdapat frase baru lagi lantunan eee dari pola ritmik yang berbeda dari sebelumnya dan begitupun seterusnya secara berulang-ulang dengan pola ritmik balaganjur Hal ini menunjukan bahwa setiap frase yang dilantunkan oleh pemain beluk, selalu berubah-ubah sesuai kebutuhan dan keinginan pelantun beluk itu sendiri. Dan dengan adanya perubahan pola ritmik, hal ini menunjukan memasuki puncak sebuah pertunjukan terebang gebes. Bagian ini berlangsung sangat lama karena dalam bagian ini terlibat interaksi antara pemain dan penonton. Berikut pola tabuh balaganjur yang dinotasikan peneliti:

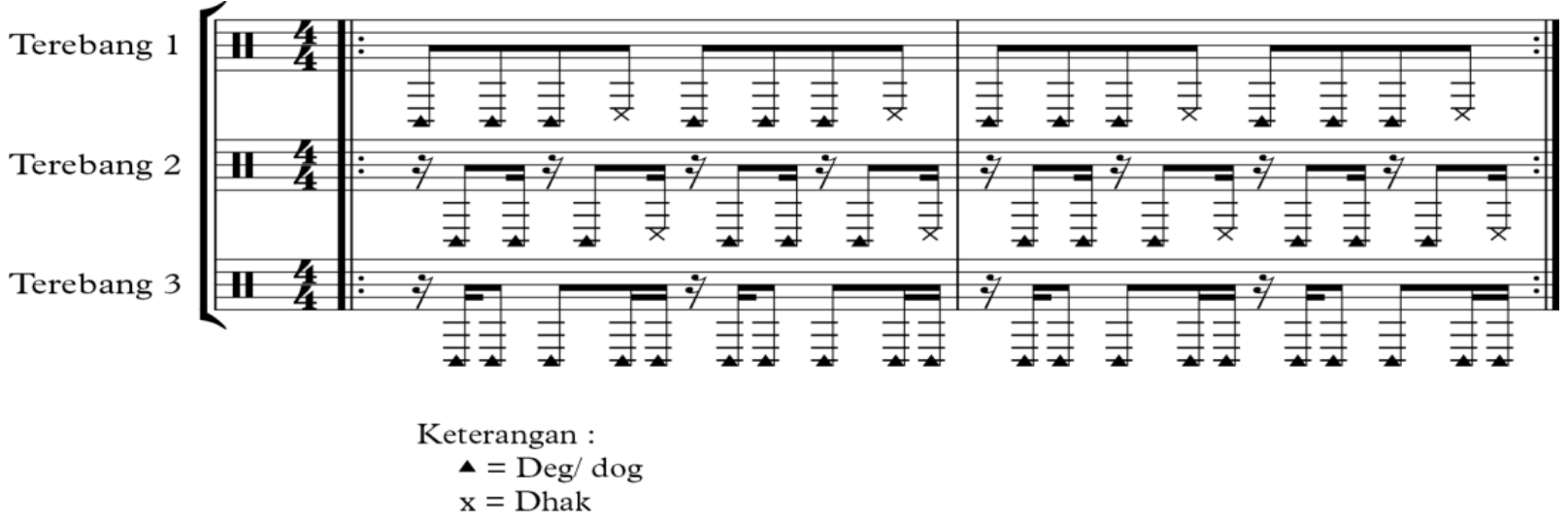

Gambar 4.4 Pola tabuh balaganjur

(Transkrip Leli Deniati, 2019)

\section{c. Bagian Penutup}

Pada bagian penutup merupakan bagian terakhir dari proses pertunjukan seni terebang gebes pola tabuhan kembali ketabuhan awal yaitu jeungjleung, degdog dan balaganjur lalu berakhir di pola tabuhan jeungjleung dan berhenti bersamaan dengan pelantun vokal beluk.
Dengan simpulan di atas, pola permainan terebang gebes dapat disederhanakan dengan uraian seperti berikut:

$$
\begin{aligned}
& \text { Motif jeungjleung }=\mathrm{A} \\
& \text { Motif degdog }=\mathrm{B} \\
& \text { Motif balaganjur }=\mathrm{C} \\
& \quad \mathrm{A}-\mathrm{B}-\mathrm{C}-\mathrm{A}-\mathrm{B}-\mathrm{A}-\mathrm{B}- \\
& \mathrm{C}-\mathrm{A}-\ldots-\mathrm{A}
\end{aligned}
$$




\section{4. $\quad$ Peran dan Fungsi seni Terebang Gebes pada Acara Hajat Lembur}

Peran dan fungsi seni terebang gebes dalam konteks masyarakat dan budaya seni terebang gebes sangat berhubungan dengan keadaan masyarakat dan Budaya setempat. Oleh karena itu, peran dan fungsi pun sangat berhubungan dengan masyarakat dan budaya setempat.

Dari sisi fungsinya, keberadaan dan kemampuan bertahan kesenian terebang gebes di Kampung Cirangkong Desa Cikeusal Kecamatan Tanjungjaya Kabupaten Tasikmalaya berkaitan dengan fungsi-fungsi terbagi dua yaitu:

\section{a. Fungsi Primer}

Fungsi primer merupakan fungsi utama dari seni pertunjukan yang menunjukan secara jelas siapa penikmatnya. Lebih lanjut diuraikan, bahwa dalam fungsi utamanya seni pertunjukan dapat di fungsikan sebagai: Sarana Ritual, Sarana Hiburan Pribadi, Presentasi Estetis. Berikut fungsi seni terebang gebes Grup Candralijaya dalam fungsi primer:

\section{1). Kesenian Tradisional Sebagai Sarana Ritual}

Berdasarkan hasil wawancara Bapak H.Ipin Saripin, AMa.Pd menceritakan secara singkat bahwa fungsi dari seni terebang gebes pada sarana ritual, pada zaman dahulu sebagai adu kesakten dilaksanakan pada zaman dulu saja sebelum Syech Abdul Muhyi menyebarkan agama Islam di tatar sunda Sukapura. Karena pada zaman dahulu benar-benar menjadi ajang adu kesakten dengan bantuan ilmu gaib (magis). Akan tetapi untuk ritual saat ini, pertunjukan seni terebang gebes dilaksanakan pada saat perayaan hari besar Islam saja untuk mengiringi sholawatan.

\section{2). Kesenian Tradisional Sebagai Sarana Hiburan}

Seperti kebanyakan fungsi seni pada saat ini yaitu sebagai hiburan semata, maka berlaku juga ketika seni itu diciptakan sebagai kemasan komoditi yang digelar pada panggung-panggung proscenium atau bisa disebut sebagai panggung bingkai. Kemasan seni tersebut tercipta dari pemikiran professional barat yang menuntut suatu idealitas bahwa kesenimanan dipandang sebagai tenaga profesi daripada karyakaryanya. Berbeda dengan objek seni yang berada sebagai kekayaan etnik suatu bangsa, yang terlahir dan hidup menjadi bagian dari sistem kemasyarakatan komunal atau sebagai nilai bersama. Terciptanya hal tersebut bukan atas landasan profesionalisme, tetapi atas dasar nilai yang terkandung didalamnya. Atas pemikiran panjang untuk menjaga keseimbangan rantai kehidupan kemanusiaan serta keberlangsungan ekosistem pada lingkungannya.

Fenomena yang terjadi pada seni terebang gebes di Desa Cikeusal Kecamatan Tanjungjaya Kabupaten Tasikmalaya sekarang ini yaitu transisi fungsi daripada fungsi ritual dan selebihnya adalah undangan-undangan untuk mengisi acara yang bersifat hiburan. Salah satunya, mengisi acara pada peresmian-peresmian suatu kelembagaan dan undangan acara untuk berkolaborasi dengan jenis musik-musik yang sifatnya baru. Walaupun pada realisasinya seolah terlihat memaksakan oleh sebab perubahan konteks yang terjadi terlalu jauh. Katakanlah kesenian tersebut hidup atas keberadaan alamnya yang begitu ramah kemudian dipaksakan untuk tampil di tengahtengah perkotaan dengan kondisi alamnya yang berbeda.

\section{3). Kesenian Tradisional Sebagai Kenikmatan Estetis \\ Menurut Alan P.Meriam (1964:223), dalam setiap kekayaan seni, sudah menjadi hokum kausal bahwa creator maupun pelakunya akan menemukan suatu peristiwa yakni}


kenikmatan estetis ketika karya itu dipentaskan. Hal ini berlaku pula untuk karya-karya yang tumbuh dan lahir dalam sistem kebudayaan, baik itu menyangkut kebutuhan ritual maupun dalam konteks kegiatan yang bersifat profane (hal duniawi). Kekayaan yang telah tercipta tidak semata lahir begitu saja, tetapi semuanya didasari atas pemikiran serta perenungan yang lama dari si penciptanya. Maka fungsi kenikmatan estetis akan menjadi sangat berlaku dalam beberapa kebudayaan di dunia.

Maka dapat di simpulkan bahwa fungsi pertunjukan seni terebang gebes Grup Candralijaya mengandung suatu kenikmatan estetis yaitu dimana pertunjukan tersebut dapat di nikmati oleh penciptanya itu sendiri maupun penonton.

\section{B. Fungsi sekunder}

Fungsi sekunder merupakan fungsi yang berada diluar fungsi utama yang diantaranya, sebagai pengikat solidaritas, sebagai media komunikasi, dan sebagai ekonomi dan edukasi . Berikut fungsi seni terebang gebes Grup Candralijaya dalam fungsi sekunder:

\section{Fungsi Seni Sebagai Pengikat Kebersamaan}

Pada fungsi ini terlihat dari pertunjukan seni terebang gebes Grup Candralijaya dari awal dan sebelum dimulainnya pertunjukan dengan adanya hajat lembur baik masyarakat Kampung Cirangkong maupun Apresiator, berkumpul disuatu tempat untuk menyaksikan bersama-sama pelaksanaan hajat lembur yang menampilkan beberapa kesenian khas Cirangkong. Hal ini membuktikan fungsi seni sebagai pengikat kebersamaan yang sebelumnya jarang terjadi yaitu dengan adanya acara ini secara tidak sadar semua masyarakat berkumpul dan bersilaturahmi.

\section{Fungsi Seni Sebagai Sarana Komunikasi/interaksi}

Pada fungsi ini terlihat dari peranan kesenian dalam kehidupan ini ditentukan oleh keadaan masyarakat, maka dari itu dengan adanya fungsi pertunjukan seni sebagai sarana komunikasi meningkatkan kondisi masyarakat dalam hal pengembangan kesenian.

\section{Fungsi Seni Sebagai Ekonomi (mata pencaharian)}

Dalam hal ini meskipun pemain kesenian terebang gebes memiliki mata pencaharian sebagai petani, selain atas dasar kecintaan para seniman terhadap kesenian terebang gebes, pertunjukan seni terebang gebes memiliki fungsi sebagai mata pencaharian. Hal ini dibuktikan dengan adanya pertunjukan terebang gebes pada undangan acara-acara yang dilaksanakan hajat seperti festival seni, khitanan, dan syukuran merupakan sebuah pertunjukan yang mendatangkan materil. Maka dari itu seni terebang gebes memiliki fungsi sebagai mata pencaharian.

\section{KESIMPULAN}

Berdasarkan hasil penelitian yang dilakukan di Kampung Cirangkong Desa Cikeusal Kecamatan Tanjungjaya Kabupaten Tasikmalaya tentang struktur penyajian seni terebang gebes Grup Candralijaya Pada acara hajat lembur, maka diperoleh suatu kesimpulan yang berkaitan dengan rumusan masalah yaitu tentang struktur penyajian seni terebang gebes serta fungsi seni terebang gebes pada acara hajat lembur dapat disimpulkan bahwa kesenian terebang gebes merupakan sebuah seni tradisional buhun yang telah berkembang sejak dulu. Meskipun pada awalnya fungsi seni terebang gebes adalah sebagai ritual adu kesakten (adu kesaktian), akan tetapi dengan perkembangan agama Islam, kini berubah fungsi menjadi sebuah seni pertunjukan sebagai sarana 
ritual, hiburan dan presentasi estetis. Selain itu, seni terebang gebes juga menjadi sebuah kesenian yang tidak hanya dipertunjukan pada acara yang diadakan Kampung Cirangkong, akan tetapi bisa ditampilkan pada acara-acara lain. Sejak keberadaan Grup Candralijaya, kesenian ini telah mengalami perkembangan baik itu dalam penambahan anggota dan penambahan properti-properti yang dibutuhkan sesuai dengan pertunjukannya. Adapun tujuan utama pertunjukan kesenian-kesenian pada acara hajat lembur khas Cirangkong, yaitu sebagai wujud syukur atas musim panen tiba.

Merujuk pada rumusan masalah mengenai struktur penyajian musik seni terebang gebes Grup Candralijaya dilihat dari jenis struktur pertunjukannya termasuk kedalam sebuah musik ansamble yang memainkan alat musik terebang yang dimainkan secara bersama-sama dengan menggunakan waditra yang sama.

Selain itu untuk motif tabuhan seni terebang gebes Grup Candralijaya terikat oleh keutuhan instrumen yang terdiri dari tiga buah terebang, dengan aturan tepak atau tabuhan terebang yang juga terikat oleh tiga aturan irama yaitu tepak jeungjleung, tepak degdog, dan tepak balaganjur.

Selanjutnya mengenai struktur penyajian musik seni terebang gebes Grup Candralijaya peneliti menyimpulkan penyajian pertunjukannya terbagi menjadi tiga bagian meliputi bagian pembuka, isi dan penutup. Pada bagian pembuka sebelum instrumen dimulai ada satu pemain terebang yang memainkan waditra terebang selama empat ketuk sebagai tanda dimulainya permainan terebang setelah itu pemain terebang yang lain masuk secara bersamsama dengan pola motif tabuhan jeungjleung, pada bagian ini merupakan sebagai pemanasan. Setelah bagian pertama dirasa cukup selanjutnya masuk ke bagian kedua yaitu bagian isi demgan pola tabuhan degdog, pada bagian ini merupakan bagian inti dengan pola ritme yang berbeda. Beberapa waktu kemudian terdapat beluk masuk dengan pola iringan degdog, lalu kembali lagi ke pola iringan jeungjleung yang berfungsi sebagai jembatan dimana sebelumnya menggunakan pola ritmik degdog. Selanjutnya masuk ke pola iringan balaganjur dengan lantunan pelantun beluk. Dan yang terakhir bagian penutup bagian terakhir dari proses pertunjukan, pola tabuhan kembali ke pola tabuhan awal yaitu jeungjleung, degdog, dan balaganjur dan berakhir di pola tabuhan jeungjleung dengan berhenti bersamaan dengan pelantun beluk.

Untuk peran dan fungsi dalam pertunjukan seni terebang gebes Grup Candralijaya, peneliti menyimpulkan bahwa fungsi seni terebang gebes ini dibagi menjadi dua bagian yaitu fungsi primer dan fungsi sekunder. Fungsi primer yang merupakan sebagai fungsi utamanya yang pertama sebagai sarana ritual yang hanya dilaksanakan pada saat perayaan hari besar seperti hajat lembur, yang kedua sebagai sarana hiburan yang semata-mata berfungsi hanya sebagai hiburan saja seperti mengisi acara undangan-undangan diacara pernikahan atau festival musik dll. Dan yang terakhir sebagai sarana presentasi estetis yang berfungsi sebagai ungkapan keindahan.

Fungsi sekunder yang merupakan kedalam fungsi yang berada diluar fungsi utama yaitu fungsi sebagai pengikat kebersamaan dengan adanya pertunjukan kesenia terebang gebes secara tidak sadar semua masyarakat berkumpul dan bersilaturahmi. Yang kedua sebagai media komunikasi dalam hal ini dengan adanya fungsi seni terebang gebes sebagai sarana komunikasi dapat meningkatkan kondisi masyarakat dalam hal mengembangkan kesenian. 


\section{DAFTAR PUSTAKA}

Caturwati, Endang. (2008). Tradisi Sebagai Tumpuan Kreativitas Seni. Bandung: Sunan Ambu STSI Press.

Djelantik, A.A.M. (1999). Estetika: Sebuah Pengantar, Masyarakat Seni Pertunjukan Indonesia. Yogyakarta: Bentang Budaya.

Sugiyono, (2011). Metode Penelitian Pendidikan ( Pendekatan Kualitatif, Kualitatif dan $R \& D)$. Bandung: Alfabeta.

Sumardjo, Jakob. (2000) Filsafat Seni. Bandung: ITB.

Soepandi, Atik (1977). Khasanah Daerah Kesenian Jawa Barat. Bandung: Pelita Masa.

Hidayati, Nia.(2015). Pertunjukan Buhun Terebang Gebes Yang Bertahan. Tersedia Online: (http://www.niahidayati.net/senipertunjukan-terebang-gebes-yangbuhun-yang-bertahan.html) di unduh tanggal 27 Juni 2019. 